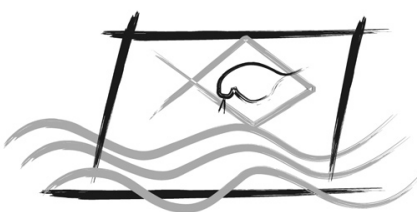

ECOTOX - BRASIL

\title{
Water toxicity assessment in the Suape estuarine complex (PE-Brazil)
}

\author{
L.P. De Souza-Santos ${ }^{1} \&$ R.J. AraúJo ${ }^{2}$ \\ ${ }^{1,2}$ Laboratório de Cultivo e Ecotoxicologia, Departamento de Oceanografia, Universidade Federal \\ de Pernambuco - UFPE, Av.Prof. Morais Rego, s/n, CEP 50740-550, Recife, PE, Brasil.
}

(Received December 05, 2011; Accept November 22, 2012)

\begin{abstract}
The Suape estuarine complex (PE, Brazil) is located close to an industrial port complex of Suape which has been responsible for altering the geomorphologic and hydrological conditions of the area. As the industrial port of Suape represents a possible source of pollution through the use and transport of chemical substances, the present research aimed to evaluate if the surface water of the estuarine complex in Suape shows chronic toxicity based on the embryo larval development of the sea urchin Lytechinus variegatus. Six sampling points were established between the estuaries of the rivers Massangana and Tatuoca. Samples of surface water from the area were collected on May, August, October and December of 2007. Chronic toxicity was observed in the six points and it varied depending on the month. The highest level of toxicity was on October when it was detected at all six points. The results showed that the water of the river Massangana was the most probable source of pollution in the area studied during this period.
\end{abstract}

Key words: port, harbour, estuary, pollution, ecotoxicology, bioassays, sea-urchin.

\section{Avaliação da toxicidade das águas do complexo estuarino de Suape (PE-Brasil)}

\section{Resumo}

O complexo estuarino de Suape (PE, Brasil) está localizado próximo ao complexo porto-industrial de Suape, o qual tem sido responsável por alterações nas condições geomorfológicas e hidrológicas da área. Como o complexo porto-industrial de Suape representa uma potencial fonte poluidora pelo uso e transporte de substâncias químicas, este trabalho teve como objetivo avaliar se as águas superficiais do complexo estuarino de Suape apresentavam toxicidade crônica baseada no desenvolvimento embriolarval do ouriço-do-mar Lytechinus variegatus. Seis pontos de coleta foram estabelecidos entre os estuários do rio Massangana e Tatuoca e amostras de água superficial do local foram coletadas nos meses de maio, agosto, outubro e dezembro de 2007. Toxicidade crônica foi observada nos seis pontos examinados e variou de acordo com o mês, sendo maior no mês de outubro, quando a toxicidade nos seis pontos foi significativa. Os resultados indicaram que as águas do rio Massangana foram as mais prováveis fontes de poluentes para a área estudada neste período.

Palavras chaves: porto, estuário, poluição, ecotoxicologia, bioensaio, ouriço-do-mar. 


\section{INTRODUCTION}

The industrial port complex of Suape in Pernambuco (Brazil) was established between the years 1979 and 1980, leading to great changes in the geomorphic and hydrological conditions of the area (Neumann et al., 1998; Muniz et al., 2005). Currently the complex contains more than 70 installations, some of which are still under construction, and includes a shipyard, an oil refinery and a petrochemical plant. All of these ventures can generate waste which can have a significant impact on the environment and can cause toxicity to the local biota. But until now, for the best of our knowledge, the very few ecotoxicological data of water samples can only be found on monitoring rapports of enterprises.

Ecotoxicological tests are important tools to assess water and sediment quality, but as yet are rarely used in the Northeast Brazil. One of the most used marine organisms in toxicity bioassays is the sea urchin, being the embryo larval development an indicator applied all over the world because of its high sensitivity (Cesar et al., 2002 and 2004; Pusceddu et al., 2007). Sea urchin tests were standardized by USEPA (1991 and 1994) and adapted for Brazilian species Lytechinus variegatus and Echinometra lucunter by the Environmental Sanitation Technology Company - CETESB (1999) and by the Brazilian Association of Standards and Techniques - ABNT (2006).

L. variegatus belongs to the Toxopneustidae family, has a green shell which is flattened underneath and has spines of varying colour from green to purple. It feeds on macroalgae and lives in sandy areas where it is abundant. It has a habit of covering itself in plant debris and small shells. This species can be found from the intertidal zones to open sea areas of almost $20 \mathrm{~m}$ depth from North Carolina (USA) to the southeast Brazil (CETESB, 1999; ABNT, 2006). These factors make it a potentially relevant species for bioassays; in addition, the use of embryo larval development of $L$. variegatus as a model to assess contamination in marine systems by phosphate contaminants (Böttger \& McClintock, 2001), HPAs (Steevens et al., 1999), metals (Kobayashi \& Okamura, 2004), sulphides (Losso et al., 2007), and organic compounds (Bellas et al., 2005) has been widely employed.

Thus, for the present research, the embryo larval development of the sea urchin $L$. variegatus was used in shortterm tests to assess the toxicity level of the surface water in the Suape Estuarine Complex between the estuaries of the rivers Tatuoca and Massangana.

\section{MATERIALS AND METHODS}

\section{Study Area}

The Suape Estuarine Complex is located between the municipalities of Cabo de Santo Agostinho ( $8^{\circ} 17^{\prime} 15.70^{\prime \prime S}$ and $\left.35^{\circ} 02^{\prime} 07.13^{\prime \prime} \mathrm{W}\right)$ and Ipojuca ( $8^{\circ} 24^{\prime} 01.40^{\prime \prime} \mathrm{S}$ and $\left.35^{\circ} 03^{\prime} 51.59^{\prime \prime} \mathrm{W}\right), 40$ kilometres south from the state capital Recife. The area used for the industrial port installation at Suape $\left(8^{\circ} 23^{\prime} 30.56^{\prime \prime} \mathrm{S}\right.$ and $\left.34^{\circ} 57^{\prime} 38.00^{\prime \prime} \mathrm{W}\right)$ is crossed by several rivers and streams (Fig. 1).

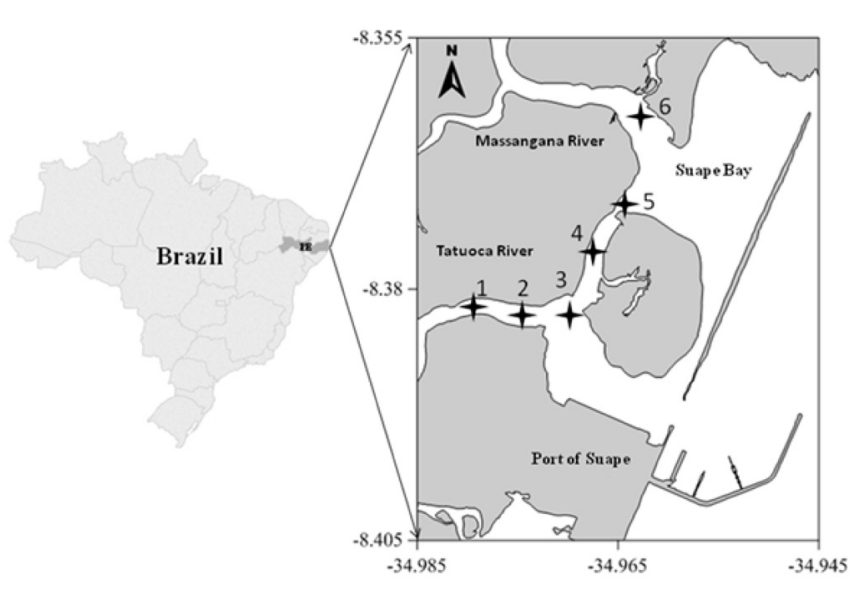

Figure 1 - Area of the Suape estuarine complex and the six sampling points.

Suape bay and the estuaries of the Massangana and Tatuoca rivers are areas which are subjected to a polyhaline/ euryhaline regime, indicating a huge influence from the nearby coastal waters (Neumann et al., 1998). The rivers Massangana and Tatuoca showed a fall in the level of their primary productivity after the river Ipojuca was blocked by the construction of Suape port. The main fertilization source of the river Massangana comes from contributions of its formative rivers (Tabatinga and Algodoais) and from the organic materials produced in its mangrove areas. The river Tatuoca has its origins in underground discharges. Upon mixing with sea water, it forms a mangrove which offers excellent living conditions for a range of organisms. The mouth of this river has had frequent dredging operations carried out in its channel, as well as partial landfills along its marginal areas, including parts of the mangrove. These activities, along with other factors, have combined to diminish the natural fertility of the rivers and contribute to its transformation into nothing more than a canal outflow.

\section{Sample Collection}

Samplings were carried out on May, August, October and December in 2007. Samples were taken from six points which were distributed between the estuaries of the rivers Tatuoca and Massangana, around the area of the Atlântico Sul Shipyard installation (Fig. 1). Two samples of $300 \mathrm{~mL}$ of surface water were taken at each collection point, using plastic bottles of $500 \mathrm{~mL}$, and kept in thermal ice-boxes before being transported to the laboratory. The second sample was used only if the first bioassay was not valid for some reason. Following regulations NBR 15350:2006 and CETESB L5. 250 - May/99, samples were frozen in the laboratory and stored in a freezer at $-20^{\circ} \mathrm{C}$, thus allowing a maximum period of 60 days to carry out the analysis. However, all samples were analysed within 15 days after collection. Salinity, temperature, $\mathrm{pH}$ and dissolved oxygen were measured in the surface water during the collection of samples using a hand refractometer, a digital thermometer, a field pHmeter, and an oximeter, respectively.

Rainfall data of the region was provided by the Meteorology Laboratory of Pernambuco/Institute of 
Technology of Pernambuco (LAMEPE/ITEP, 2008), which has a meteorological data collection station in the municipality of Cabo de Santo Agostinho at Suape Dam.

\section{Specimen Collection}

The sea urchins $L$. variegatus were collected one week before carrying out the tests, just to the south of the studied area, on Muro Alto beach ( $8^{\circ} 25^{\prime} 28.06^{\prime \prime}$ S and $\left.34^{\circ} 58^{\prime} 25.45^{\prime \prime} \mathrm{W}\right)$, in the municipality of Ipojuca on the southern coast of Pernambuco. Collection was done by free diving to depths varying between 0.5 and $4 \mathrm{~m}$. The collected animals were kept in thermal ice-boxes until being brought to the laboratory where they were placed in a seawater aquarium (previously stabilized) and fed with macroalgae Ulva sp. sampled in the same place.

\section{Dilution Seawater}

The seawater used in tests with the reference substance and controls was donated by Aqualider, a company which produces post larva of the marine shrimps. This company collects water directly from the sea and gives it special treatments in order to use it in the hatchery. Treatment consists in passing the seawater through sand filters of different granulations; subsequently it is radiated with ultraviolet, chlorinated and dechlorinated. This treated seawater was kept in boxes of water in the laboratory and filtered using $\mathrm{CUNO}^{\circledR}$ filters with a porosity of 25 and $3 \mu \mathrm{m}$ and adjusted to salinity of 33 before use.

\section{Toxicological Tests}

The short term chronic toxicity tests on $L$. variegatus were carried out based on ABNT 15350/2006 and CETESB L5. 250 - May/99 protocols, in which sea urchin embryos were exposed to test water samples for 24 to 28 hours, and it was evaluated the number of larvae (Pluteus) showing normal (well formed) and anomalous (badly formed) development when compared to controls.

Previously collected estuary surface water samples were thawed in an environment protected from heat and direct sunlight, and they were ready for analysis when they reached a temperature of $25 \pm 1{ }^{\circ} \mathrm{C}$. Before the tests, measurements of salinity, temperature, $\mathrm{pH}$ and dissolved oxygen were taken again. When necessary, the salinity levels were adjusted with brine, prepared after the freezing of the filtered seawater samples, or by adding distilled water. Five subsamples of 10 $\mathrm{mL}$ were taken from one replicate sample from each sampling points and were placed in $40 \mathrm{~mL}$ glass test tubes with 300 fertilized $L$. variegatus eggs. The test tubes were brought to a $12 \mathrm{~h}$ light/dark photoperiod controlled incubator and kept in a controlled temperature of $25^{\circ} \mathrm{C}$. The test was ended after 28 hours, when at least $80 \%$ of the control organisms had reached the well developed pluteus stage. This was verified by identifying the development stage of the first 100 organisms from one of the control replicates. Then the contents were fixed using $2 \%$ formol buffered with borax. The development stage and the incidence of anomalies in the first 100 organisms of each replica were observed using a Sedgwick-Rafter counting cell. Pre-pluteus larvae, poorly developed pluteus when compared to the control and deformed or badly formed organisms were considered to be abnormal.

Sensitivity tests using sodium dodecyl sulphate (SDS) as reference substance were also performed in order to estimate a control-chart (Cesar et al., 2002). Those tests were performed in quadruplicate using a control (filtered seawater without SDS) treatment and six SDS concentrations diluted in filtered seawater $\left(0.125 ; 0.25 ; 0.50 ; 1.0 ; 2.0 ; 4.0 \mathrm{mg} \mathrm{L}^{-1}\right)$. Both tests with estuarine water samples and reference substance were simultaneously performed.

\section{Data Analysis}

Using the percentage of badly formed Lytechinus variegatus pluteus, it was possible to calculate the effective SDS concentration which cause anomalies and/or slow down the embryo larval development to $50 \%$ of the test organisms $\left(\mathrm{EC}_{50}\right)$ to each bioassay, using the EPA PROBIT version 1.5 program. The control chart of SDS was estimated from five different bioassays and the general mean $\left(\mathrm{EC}_{50}\right)$ and confidence interval was estimated for this species population.

The comparison of well formed pluteus percentages between sampling points and control water was done using ANOVA $(\alpha=$ 0.05 ), after verifying the data normality (Kolmogorov-Smirnov test; $\alpha=0.05$ ), and the homogeneity of the variances (Bartlett test; $\alpha=0.05$ ). When significant differences were found, the Tukey a posteriori test was used. For data which didn't show normality or homoscedastic, the non-parametric Kruskal-Wallis test was carried out. When the mean percentage of a sampling point was significant smaller than the control mean, the water sample was considered to be toxic.

\section{RESULTS}

Rainfall was similar to average historical levels for the region with a rainy season from March to August and a dry season from September to February. The salinity, temperature, dissolved oxygen and $\mathrm{pH}$ in the water at sampling are in Tab. 1. In the rainy season, on May, salinities were predominantly from seawater at levels of 31 and 34 in sampling points 1,2 and 6, while other points had the value of 28. On August, at points 1, 2, 3 and 6 , salinities varied from 31 to 35 while it was 27 at both points 4 and 5. In both periods the variation observed can be attributed to higher influence of freshwater. During the dry season, on October, salinities varied from 31 to 33 similar to previous months, and on December, there were at higher salinity levels $(39-40)$.

Five SDS tests were considered valid, i.e. they had a higher than $80 \%$ percentage of well formed pluteus larvae in the control $(84.59 \pm 1.6 \%)$. $\mathrm{EC}_{50}$ values of SDS for population of $L$. variegatus on Muro Alto beach was of $1.83 \pm 0,7 \mathrm{mg} \mathrm{L}^{-1}$ (mean \pm confidence interval) (Fig. 2). 
Table 1 - Result of the physical and chemical analysis of the surface water in the Suape Estuarine Complex between May and December 2007.

\begin{tabular}{|c|c|c|c|c|c|c|c|c|}
\hline Date & LT & HT & Poin & t Hour & $\mathrm{T}^{\circ} \mathrm{C}$ & $\mathbf{p H}$ & SAL & DO \\
\hline \multirow[t]{6}{*}{$\begin{array}{l}\text { 22.May } \\
.2007\end{array}$} & $01: 51-0.8 m$ & $08: 00-1.8 m$ & 1 & $09: 30$ & 27.7 & 8.0 & 31 & 4.4 \\
\hline & & & 2 & 09:56 & 27.9 & 8.0 & 34 & 5.9 \\
\hline & & & 3 & 10:18 & 27.4 & 7.9 & 28 & 5.7 \\
\hline & & & 4 & $10: 33$ & 27.7 & 8.1 & 28 & 5.5 \\
\hline & & & 5 & $10: 42$ & 27.5 & 7.9 & 28 & 5.1 \\
\hline & & & 6 & $10: 55$ & 27.5 & 7.9 & 31 & 5.3 \\
\hline \multirow[t]{6}{*}{$\begin{array}{l}\text { 08.Aug } \\
.2007\end{array}$} & $06: 02-0.6 m$ & $12: 23-1.8 m$ & 1 & $09: 35$ & 26.3 & 8.0 & 31 & 4.8 \\
\hline & & & 2 & 09:55 & 27.8 & 8.1 & 33 & 5.7 \\
\hline & & & 3 & $10: 15$ & 26.9 & 8.2 & 35 & 5.1 \\
\hline & & & 4 & $10: 28$ & 27.6 & 8.4 & 27 & 5.3 \\
\hline & & & 5 & $10: 38$ & 27.7 & 8.4 & 27 & 4.9 \\
\hline & & & 6 & $10: 55$ & 27.6 & 8.6 & 31 & 5.9 \\
\hline \multirow[t]{6}{*}{$\begin{array}{l}\text { 23.Oct. } \\
2007\end{array}$} & $08: 00-0.4 m$ & $14: 02-2.1 \mathrm{~m}$ & 1 & 09:40 & 28.0 & 7.9 & 31 & 4.1 \\
\hline & & & 2 & $10: 18$ & 28.0 & 7.9 & 31 & 4.6 \\
\hline & & & 3 & $10: 31$ & 28.2 & 7.9 & 32 & 3.8 \\
\hline & & & 4 & $10: 58$ & 28.6 & 7.9 & 31 & 3.5 \\
\hline & & & 5 & $11: 12$ & 28.8 & 7.9 & 32 & 4.5 \\
\hline & & & 6 & $11: 40$ & 28.6 & 7.9 & 33 & 4.2 \\
\hline \multirow[t]{6}{*}{$\begin{array}{l}\text { 11.Dec. } \\
2007\end{array}$} & $10: 34-0.5 m$ & $16: 08-2.1 m$ & 1 & $10: 00$ & 29.2 & 7.7 & 40 & 3.5 \\
\hline & & & 2 & $10: 25$ & 29.0 & 7.7 & 40 & 3.5 \\
\hline & & & 3 & $10: 35$ & 29.1 & 7.8 & 39 & 3.6 \\
\hline & & & 4 & $10: 50$ & 29.3 & 7.8 & 39 & 3.8 \\
\hline & & & 5 & 11:00 & 30.2 & 7.8 & 40 & 3.9 \\
\hline & & & 6 & $11: 30$ & 29.2 & 7.6 & 39 & 3.2 \\
\hline
\end{tabular}

Abbreviations: $\mathrm{LT}=$ Low Tide; HT $=$ High Tide; DO = Dissolved Oxygen in $\mathrm{mg} \mathrm{L}^{-1} ; \mathrm{SAL}=$ Salinity and $\mathrm{T}^{\circ} \mathrm{C}=$ Temperature in ${ }^{\circ} \mathrm{C}$.

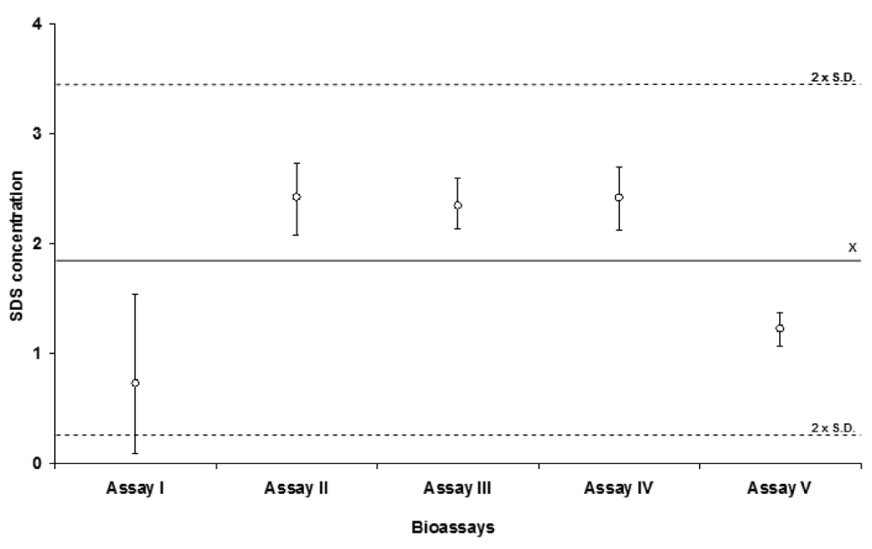

Figure 2 - Mean values ( \pm standard deviation) of $\mathrm{EC}_{50}$ in $\mathrm{mg} \mathrm{L}^{-1}$ of Sodium Dodecyl Sulphate - $\mathrm{C}_{12} \mathrm{H}_{25} \mathrm{NaO}_{4} \mathrm{~S}$ (SDS) after 28 hours in each of the five bioassays with Lytechinus variegatus collected from Muro Alto -PE, Brazil.

On May 2007, the percentage of well formed pluteus varied significantly between sampling points $(\mathrm{K}-\mathrm{W}=15.333$, $\mathrm{p}=0.017$ ), Tukey's test showed that means of stations 1 to 5 were similar to control mean and were not toxic at all but at the station 6 the percentage was lower than control one, showing toxicity (Fig. 3a).

On August 2007, the percentage of well formed pluteus varied significantly between points $(\mathrm{K}-\mathrm{W}=17.459 ; \mathrm{p}=0.007)$.
Tukey's test showed that points 4, 5 and 6 showed significant lower means when compared to the control (i.e. toxicity), and that point 4 showed the lowest percentage of well formed $L$. variegatus pluteus (Fig. 3b).

On October 2007, construction began on a new road which would cross the river Tatuoca between sampling points 1 and 2. Thus the boat used for sampling was unable to reach point 1 . Therefore, the position of collection point 1 was slightly displaced and moved closer to collection point 2 . In this month the percentage of well formed pluteus varied significantly between points $(F=29.950 ; p<0.00001)$. Tukey's test showed that all points were different from the control and showed toxicity. Once again, point 4 was the one which had the lowest percentage of well formed pluteus. Points 1, 2, 3, 5 and 6 showed no differences between each other (Fig. 3c).

On December 2007, the percentage of well formed pluteus varied significantly between collection points $(\mathrm{F}=$ $31.039 ; \mathrm{p}<0.00001)$. Tukey's test indicated that points 3,4 , 5 and 6 showed toxicity. On this month, point 6 , followed by point 3 , showed the lowest percentage of well formed pluteus (Fig. 3d).

Toxicity at the sampling points varied between the months analyzed. Point 6 showed toxicity on every month with an average pluteus formation of $47.5 \pm 16.7 \%$. The toxicity in the area was at its worst on October 2007, with toxicity in all sampling points.

\section{DISCUSSION}

The five tests with the reference substance SDS showed an $\mathrm{EC}_{50}$ provisional average $(\mathrm{n}=5)$ of $1.83 \pm 0.7 \mathrm{mg} \mathrm{L} \mathrm{L}^{-1}$. All five results are within the control limits (mean \pm 2 standard deviation), and are thus considered valid for the composition of the control-chart (USEPA, 1994; ABNT, 2006). However, the variation coefficient was still very high at $43.61 \%$ and more tests are need to a better determination of the control-chart.

Water samples collected in point 6 , located in the estuary of the river Massangana, showed chronic toxicity in the four sampling months, both in dry and rainy seasons. This toxicity should be due to the intense industrial activities in the tributaries of this river. In the Algodoais stream, a tributary of the river Massangana, Mendonça (2005) using the bacteria Vibrio fischeri as a test organism and the microcrustacean Daphnia magna, found toxicity in the waste of three companies from the beverage, metallurgy and textile sectors. Levels of toxicity were also detected downstream from the three companies in the same stream.

At the beginning of the monitoring strategy, the samples were not taken on low tides, when effects of pollution were expected to be more important. This technical trouble was resolved only from the second sampling collection onwards. On May 2007, the samplings were carried out near high tide period, in the middle of the rainy season. Only the point situated in the estuary of the river Massangana showed toxicity, 

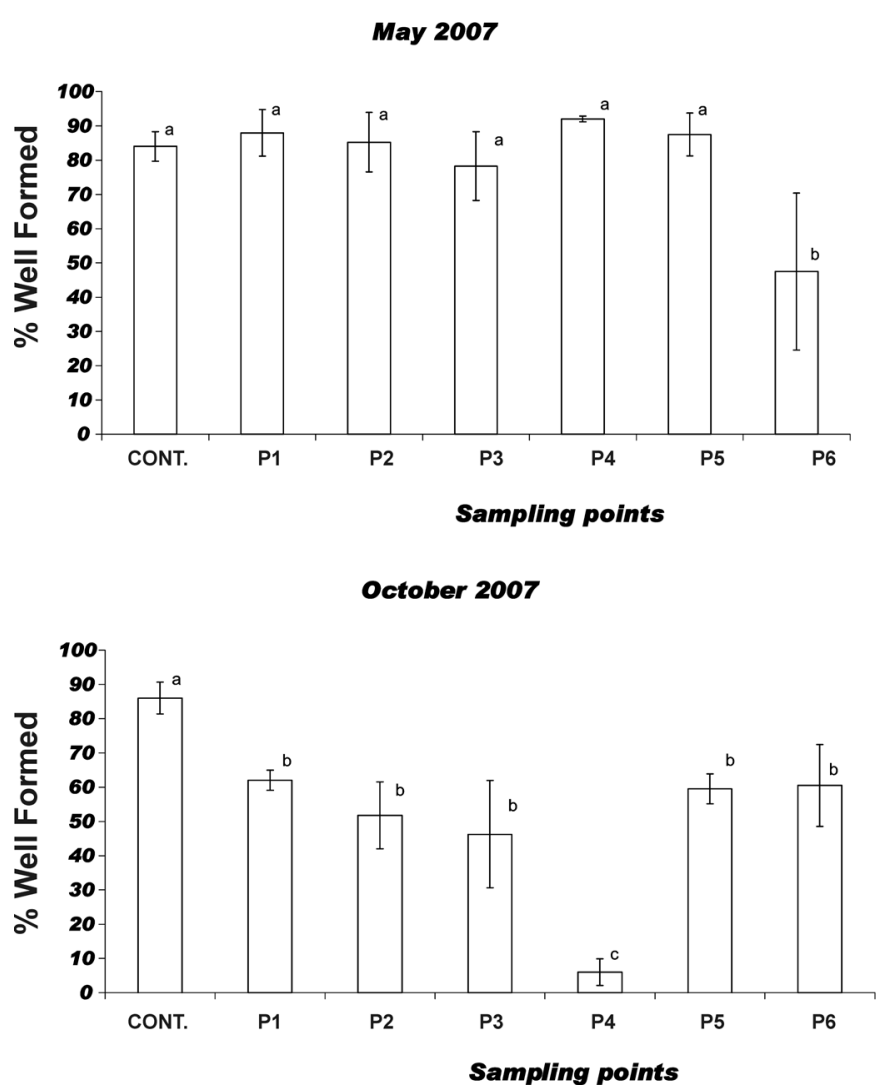

August 2007
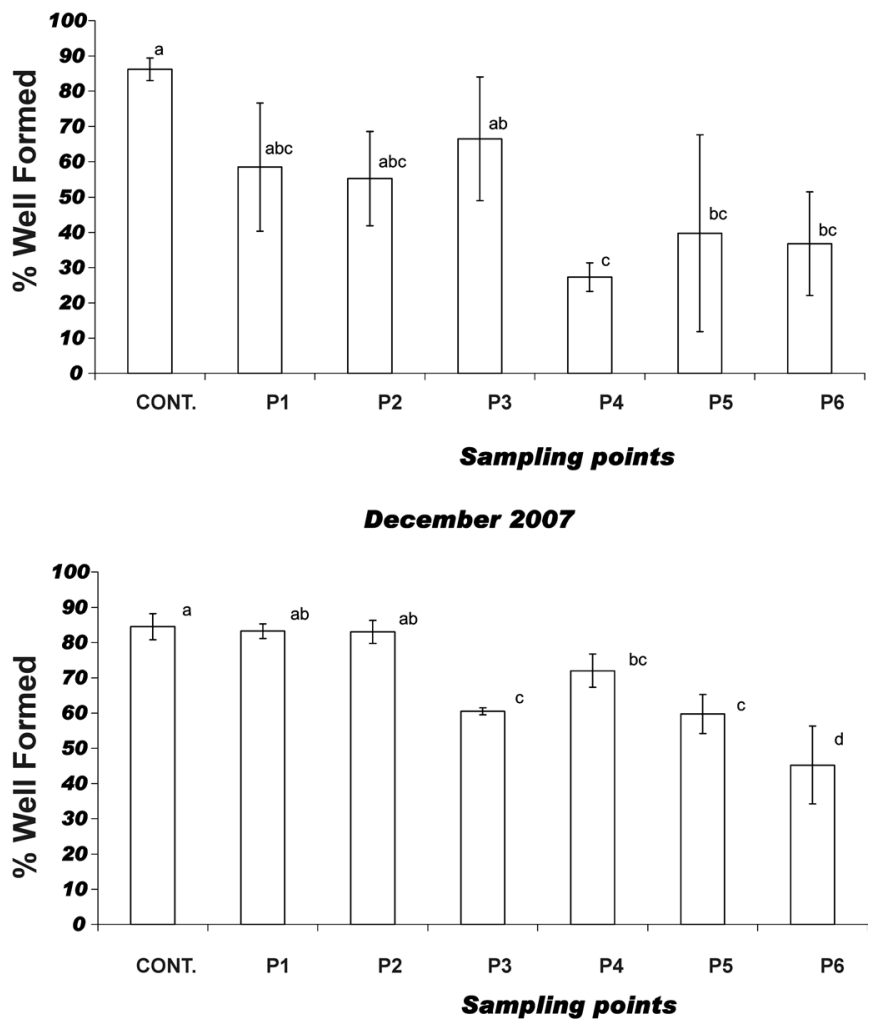

Figure 3 - Mean ( \pm deviation standard) percentage of well formed Lytechinus variegatus pluteus in the control and at the sampling points in the Suape Estuarine Complex between May and December 2007. Letters a, b and c show the significant differences $(\mathrm{p}<0.05)$ in Tukey's test.

probably due to the dilution of local water of the other points by the combined waters of the high tide and the rainfall.

On August 2007, at the end of the rainy season, the toxicity from the Massangana (P6) spread and penetrated the canal in the south (P5 and P4), between the mainland and the island of Cocaia, due to the less powerful flow of the river Tatuoca when compared with the Massangana and to the water circulation pattern in the bay of Suape (from North to South) (Moacyr Araújo, non published data).

The month of October 2007, the toxicity spread to points 3 , 2 and 1 in Tatuoca River. Even though it was at the beginning of a dry period, the salinities still indicated the influence of riverine waters. This month represented the worst levels of toxicity in surface water in all the area. Considering the fact that the river Massangana has a more powerful flow than the river Tatuoca, and in the previous months it could be seen the spread of the toxicity through the canal, one can hypothesise that the waters of the river Massangana affected the waters of the Tatuoca at this time. Another possible source of pollution could have been the waters of the Tatuoca itself. The source of the river is located in an area crossed by highways and is close to industrial and sugar cane plantations. During periods of heavy rain, industrial waste and products used by the nearby plantations such as fertilizers and pesticides, could have leached into the waters of the river Tatuoca.

Gunkel et al. (2007) evaluated the influence of the sugar cane industry on the waters of the river Ipojuca (Ipojuca -
PE) and stated that industrial waste and products used by the sugar cane plantations can significantly contaminate the waters of the river Ipojuca one or two days after torrential rain. The impact of sugar cane effluent (vinasse) on the waters of the river Ipojuca can be seen by the reduction of oxygen concentration during the dry period. Something similar could occur in the waters of the Massangana and Tatuoca rivers and consequently, the waters of the Suape estuarine area. These are all in close proximity to the river Ipojuca and the water quality can be influenced by similar factors.

Investigating the toxicity of integral (solid phase) sediment between 2002 and 2003 in Suape bay, using the harpacticoid copepod Tisbe biminiensis as a test organism, Araújo-Castro (2008) only found evidence of lethal toxicity in the Massangana river mouth in the dry season (February). However, the same study made between 2005 and 2006 revealed sub-lethal levels of toxicity at all sampling points on different months of the year, with the rainy season being the most critical. These results indicate a difference in the availability of contaminants between the dry and rainy seasons, and highlight the waters of the river Massangana as one of the main sources of pollution in the area, as revealed in the present study. This study could not found the main cause of the toxicity on sediments as metals and hydrocarbons concentrations estimated in 2002/2003 and 2005/2006 were at low levels compared with national and international probably effective concentrations. 
At Tatouca river (P1, 2 and 3), the present study only detected water toxicity on October (points 1,2 and 3) and December (point 3), months with lower rainfall. The river Tatuoca could have accumulated waste during the rainy season and showed the effects later at the beginning of the dry season (October). As the drought continues, it quite possibly reduces the influence of the Massangana's waters on the river Tatuoca (December).

Work on the highway which crosses the Tatuoca, which began in the month of October, was almost finished by December. This highway was partially blocking the waters of the Tatuoca and was increased the influence of estuarine water of Suape bay on the points 1 and 2. Therefore, one reason more to attribute the toxicity level found at Tatuoca in October 2007 probably to Massangana influence. If toxic contaminants came from the navigation canal and the internal area of Suape port, it should have been the same in December, but this was not the case. These results indicate that the internal port of Suape was probably not the main responsible for the toxicity found in the river Tatuoca. Results obtained on December 2007, reinforce the hypothesis that the waters of the river Massangana, was the main transporter of toxic substances into the Suape estuarine area.

The results obtained in this research are related to chronic short term effects observed on the embryo larval development of $L$. variegatus, which indicate that the region studied does not yet show alarming levels of pollution, but show the impact of industrial activity in the area. However, more research is necessary to identify the main sources of pollution which are endangering this complex.

\section{ACKNOWLEDGEMENTS}

This work was supported by Atlântico Sul enterprise and Rodolfo Jorge Vale de Araújo had a CNPq grant during his master course.

\section{CONCLUSIONS}

Chronic toxicity in the surface water of the Suape estuarine complex is a problem on all four months studied in 2007. It is more serious at the beginning of the dry season (October). The scattered pattern of the toxicity throughout the months of the year and the various sampling points suggests that the main polluting source in the area is the estuary of the river Massangana. This study also confirmed the sensitivity of the embryo larval development of $L$. variegatus test.

\section{REFERENCES}

ABNT (Associação Brasileira de Normas Técnicas), 2006, Aquatic Ecotoxicology: Chronic short term toxicity. Method of testing with the sea urchin (Echinodermata: Echinoidea). Tech. standard NBR 15.350, RJ, ABNT, 17p.

ARAÚJO-CASTRO, C.M.V. 2008, O copépodo marinho bentônico Tisbe biminiensis como organismo-teste em avaliações toxicológicas de sedimentos estuarinos. Tese (Doutorado em Oceanografia) - Universidade Federal de Pernambuco.

BELLAS, J.; BEIRAS, R.; MARIÑO-BALSA, J. C. \& FERNÁNDEZ, N., 2005, Toxicity of Organic Compounds in Marine Invertebrate Embryos and Larvae: A Comparison between the Sea Urchin Embryogenesis Bioassay and Alternative Test Species. Ecotoxicol., 14: 337-357.

BÖTTGER, S.A. \& McCLINTOCK, J.B., 2001, The effects of organic and inorganic phosphates on fertilization and early development of the sea urchin Lytechinus variegatus (Echinodermata: Echinoidea). Part C129, pp. 307-315.

CESAR, A.; MARÍN-GUIRAO, L.; VITA, R. \& MARÍN, A., 2002, Sensitivity of Mediterranean amphipods and sea urchins to reference toxicants. Cienc. Mar. , 28: 407-417.

CESAR, A.; MARÍN, A.; MARÍN-GUIRAO, L. \& VITA, R., 2004, Amphipod and sea urchin tests to assess the toxicity of Mediterranean sediments: the case of Portman Bay. Sci. Mar., 68: 205-213. http://dx.doi.org/10.3989/scimar.2004.68s1205

CETESB (Companhia de Tecnologia de Saneamento Ambiental), 1999, Seawater: chronic short term toxicity test with Lytechinus variegatus, Lamarck, 1816 (Echinodermata: Echinoidea). Test method - L 5.250, São Paulo, Cetesb, 22p.

GUNKEL, G; KOSMOL, J; SOBRAL, M; ROHN, H; MONTENEGRO, S \& AURELIANO, J., 2007, Sugar cane industry as a source of water pollution - case study on the situation in Ipojuca River; Pernambuco, Brazil. Water Air Soil Pollut., 180: 261-269. http://dx.doi.org/10.1007/s11270-0069268-X

KOBAYASHI, N. \& OKAMURA, H., 2004, Effects of heavy metals on sea urchin embryo development.1. Tracing the cause by the effects. Chemosphere, 55: 1403-1412. http://dx.doi. org/10.1016/j.chemosphere.2003.11.052

KOENING, M. L.; LEÇA, E. E.; NEUMANN-LEITÃO, S. \& MACÊDO, S. J., 2003, Impact of the construction of the Port of Suape on phytoplankton in the Ipojuca river estuary (Pernambuco - Brazil). Braz. Arch. Biol. Technol., 46: 73-81.

LAMEPE/ITEP -Meteorological Laboratory of Pernambuco of the Institute of Technology of Pernambuco, 2008, www.itep.br/ LAMEPE.asp, accessed in 15 Sep 2008.

LOSSO, C.; NOVELI, A.A.; PICONE, M.; MARCHETTO, D.; PANTINE, C.; GHETTI, P.F. \& GHIRARDINI, A.V., 2007, Potential role of sulfide and ammonia as confounding factors in elutriate toxicity bioassays in the early life stages of sea urchins and bivalves. Ecotoxicol. Environ. Saf., 66: 252-257. http:// dx.doi.org/10.1016/j.ecoenv.2005.12.008

MENDONÇA, V. S., 2005, Evaluation of acute toxicity of industrial effluent in the Algodoais stream. Recife: State Agency of the Environment and Water Resources - CPRH. 22p.

MUNIZ, K.; NETO, B. B.; MACÊDO, S. J. \& PINHEIRO FILHO, W. C., 2005, Hydrological Impact of the Port Complex of Suape on the Ipojuca River (Pernambuco - Brazil). J. Coast.l Res., 21: 909-914. http://dx.doi.org/10.2112/03-0070.1

NEUMANN, V. H.; MEDEIROS, C.; PARENTE, L.; LEITÃO, S. N. \& KOENING, M. L., 1998, Hyrodynamism, Sedimentology, Geomorphology and Plankton Changes in the Suape Area (Pernambuco - Brazil) after a Port Complex Construction. An. Acad. Bras. Cienc., 70: 313-323.

PUSCEDDU, F. H.; ALEGRE, G. F.; PEREIRA, C. D. S. \& CESAR, A., 2007, Evaluation of the toxicity of the sediment in the estuarine compound of Santos using the sea urchin Lytechinus variegatus (Echinoidea: Echinodermata). J. Braz. Soc. Ecotoxicol., 2: 237242.

STEEVENS, J.A.; SLATTERY, M.; ARYL, A. \& BENSON, W.H. SCHLENK, D., 1999, Effects of ultraviolet-B light and 
polyaromatic hydrocarbon exposure on sea urchin development and bacterial bioluminescence. Mar. Environ. Res., 48: 439-457. http://dx.doi.org/10.1016/S0141-1136(99)00061-6

U.S. EPA (Environmental Protection Agency), 1991, Guidelines for Developmental Toxicity Risk Assessment. EPA- 600-FR-91/001.
Washington, USA, Federal Register 56(254):63798-63826.

U.S. EPA (Environmental Protection Agency), 1994, Short-Term Methods for Estimating the Chronic Toxicity of Effluents and Receiving Waters to Marine and Estuarine Organisms. EPA/600/4-91/003. Washington, USA, Second Edition, 437 p. 